\title{
Information Literacy Practices of Spanish-Speaking Graduate Students at the University of Kansas
}

Betsaida M. Reyes, Alison Hicks, and Bronwen K. Maxson

abstract: Recognizing the importance of designing educational opportunities that draw upon students' prior knowledge and experiences, this paper uses focus groups to explore how Spanishspeaking students in a graduate program at the University of Kansas (KU) in Lawrence understand academic information literacy practices within their new cultural contexts. This paper demonstrates that a variety of interwoven scholarly and sociocultural pressures mediate graduate student information activities. Findings from this paper broaden understandings of information literacy within today's diverse information environments while also highlighting the need for librarians to engage with the complexity of graduate student experiences.

\section{Introduction}

In a library instruction session for a Spanish undergraduate course, one of the authors of this paper noticed a student selecting resources for his research project by browsing book covers from the results of a Google Image search. Aware that the student's choice of material would probably not be accepted as a suitable source by the professor, the librarian approached him and demonstrated how to use Boolean operators and quotation marks to carry out a search in both the library catalog and in WorldCat, which lists the holdings of tens of thousands of libraries worldwide. Despite the librarian's efforts, the student resisted her attempt to help, preferring his visual way of finding information. The student in question is a heritage speaker of Spanish. As we thought more about this incident, we started to wonder what other innovative strategies students used to make sense of academic research, especially students working in a second or 
third language. What understandings about information literacy (IL) do multilingual students bring to their studies in the United States? What tactics do these students employ to deal with cultural and linguistic disconnect? Most importantly, how is a multilingual student's transition, within these new academic and sociocultural contexts, mediated through both standard and unrecognized IL practices? These questions drive this exploration into the academic IL practices of Spanish-speaking graduate students at the University of Kansas, defining a graduate student as an individual currently engaged in post-baccalaureate education.

More than 2,000 international students attend the University of Kansas, a large public research university in Lawrence. The National Research Council, the research arm of the National Academies of Science, Engineering, and Medicine, named the university's Spanish and Portuguese Department as one of the most distinguished graduate programs in Spanish. ${ }^{1}$

This paper provides an overview of the research problem that structures this study, reviews the literature on Spanish and international student IL, and explores the findings from three focus groups at the University of Kansas to examine the academic IL practices of Spanishspeaking graduate students. Finally, this paper will provide takeaway recommendations for librarians. Although the study centers on Spanish-speaking graduate students, the emphasis on multilingualism means that this research will interest world language librarians, as well as librarians who work in area studies or with multilingual, multicultural, or international populations.

\section{Research Problem}

With the ongoing push toward the internationalization of campuses, the number of international students continues to rise. ${ }^{2}$ In 2015-2016, the United States welcomed over 82,000 students from Spanish-speaking countries. ${ }^{3}$ Graduate students represent almost 29 percent of this number. ${ }^{4}$ As 
Latin American and Spanish librarians, the authors of this paper work with such students throughout their master's and $\mathrm{PhD}$ education and recognize the need to design learning experiences that build upon these students' prior knowledge and understanding. Although library and information science (LIS) research has developed a growing literature on international students, ${ }^{5}$ most IL studies to date have tended to focus on measuring student proficiency against a series of standard competencies rather than on recognizing and exploring the knowledge that multilingual learners bring with them. ${ }^{6}$ These studies often fail to account for cultural and linguistic differences as well as for the educational methods that have worked for these students in the past. ${ }^{7}$ Studies also neglect to consider the broader sociocultural realities that affect learning, including these students' transition toward becoming scholars while living as an ethnic or linguistic minority in a majority culture. By focusing on what students do rather than "what they do not do when compared to a dominant group," 8 this paper aims to contribute to the design of IL teaching that respects and builds upon students' experiences and understandings.

This research problem draws from ideas and recent developments within the fields of literacy and IL studies. In recognizing that there is no single, standard way of understanding and looking at IL around the globe, this study adopts a sociocultural perspective to learning and knowing. A sociocultural approach to IL emerges from sociocultural theories of learning, based on the idea that learners construct knowledge through their participation in social activity. The study draws from the understanding that IL is a situated practice that emerges from, and is influenced by, the activities of a specific group of people. ${ }^{9}$ This focus on the sociocultural influences that shape an individual's activity highlights that IL must be explored in context rather than as a series of fixed steps to be followed or habits of mind to be developed. ${ }^{10}$ The sociocultural perspective also informs the study's use of the term IL practices, which refocuses 
attention away from individualized skills and behaviors to center instead upon the information activities and ways of knowing that emerge from and constitute collective and community-based understandings of literacy. ${ }^{11}$

This paper also reflects understandings from new literacy studies research and practice, which sees literacy as situated within and shaped by a specific community. ${ }^{12}$ Research from new literacy studies positions cultural difference as complex rather than as reduced to essentials and fixed. Understanding cultural difference as "proclivities of people with certain histories of engagement with specific cultural activities" rather than as a static, individual trait, ${ }^{13}$ these ideas recognize that Spanish-speaking students' information activities are not driven by an essential, innate cultural style. Instead, individuals participate in the dynamic practices of multiple communities. This idea is particularly important in the current study, where participants hail from varied Spanish-speaking national, ethnic, and social groupings. This study should be interpreted as an attempt to explore how Spanish information realities affect and have affected student research and information activities rather than as an effort to discover the definitive "essence" of Spanish IL.

Lastly, this paper draws from social science research to take a strengths-based approach to learning and to recognize students as experts about their own experiences. ${ }^{14}$ As Rosemary Green points out, students often develop a wide range of relevant and useful IL strategies. Yet “individualized, tacit, unrecognized, or differently named" practices may go unrecognized by librarians who are accustomed to viewing IL through the lens of institutional or professional competency documents. ${ }^{15}$ In centering our study on the learner rather than on the information skills, we hope to gain a deeper understanding of where these learners come from as well as what their future needs will be. This approach is reinforced through IL scholarship, ${ }^{16}$ as well as by the 
ethos behind the Association of College and Research Libraries (ACRL) Framework for Information Literacy for Higher Education. ${ }^{17}$

\section{Literature Review}

\section{Spanish-Language IL Practices}

Although the term IL is not new in the Spanish lexicon, appearing first in a 1996 doctoral dissertation from Spain, ${ }^{18}$ the idea has only recently become mainstream. It has attracted interest from such organizations as the European Union and UNESCO. ${ }^{19}$ A report from the International Federation of Library Institutions and Associations (IFLA) declared IL as "essential for the creation of an adequate framework to access information in libraries" (our translation).

Scholarship in the area has now broadened to focus, like most English-language research, on IL in academic settings throughout Ibero-America, defined as Spanish-speaking and Portuguesespeaking countries in the Americas, and in the Spanish-speaking and Portuguese-speaking countries of Europe. ${ }^{20}$

One of the major strands in Ibero-American research explores both the reach and the shape of IL within Spanish-speaking countries. Spearheaded by the efforts of Alejandro UribeTirado from Colombia, among others, this work provides a useful snapshot of programmatic approaches to IL and helps to establish the context for the information experiences of incoming Spanish-speaking students. Research into the development of IL programs in Spain, for example, demonstrates that only 57 percent (74 of 131) of university libraries offer some form of information training, of which just over one-third ( 29 of 74 ) center on IL rather than on basic user education. ${ }^{21}$ In Latin America, however, the number of IL programs is much lower, with just 13.5 percent (72 of 532) of university libraries in Mexico providing any sort of education outreach. ${ }^{22}$ Overall, differing educational goals and economic opportunities mean that libraries in 
the region do not yet support IL as a priority. Moreover, IL is rarely mentioned beyond academic libraries, ${ }^{23}$ although Edilma Naranjo-Vélez and Nora Elena Rendón-Giraldo note a few examples of IL in public and school libraries, ${ }^{24}$ and Elisabeth Dudziak makes a strong case for linking IL to development and business contexts. ${ }^{25}$

Given these implementation challenges, how is IL currently understood in IberoAmerica? In 2015, María Pinto, M. Isabel Escalona, Antonio Pulgarín, and Alejandro UribeTirado analyzed the six periods of Ibero-American IL research. They found that Anglophone standards, models, and literature strongly influenced early visions of IL. ${ }^{26}$ Since then, the growth of informal and individual efforts, ${ }^{27}$ as well as the presence of IL within national and international Ibero-American initiatives such as the 2012 Havana Declaration, ${ }^{28}$ have helped make IL more contextualized. Understanding is complicated, however, both by the number of terms that can be used to describe IL in Spanish-Uribe-Tirado lists 10 translations on his blog 29 _ as well as by several ways to think about IL. The participants in a 2015 study by Gloria Ponjuán, María Pinto, and Alejandro Uribe-Tirado reported the use of no fewer than 14 definitions throughout the region. ${ }^{30}$ Literature reviews by the team of María Pinto, Gloria Ponjuán, Mercedes Fernández, and Dora Sales Salvador and by the partnership of Maria Lourdes Tiscareño Arroyo and José de Jesús Cortés-Vera demonstrate that the Spanish-speaking students will likely arrive in the United States with a range of understandings about IL practices. ${ }^{31}$ Work by Jorge Winston Barbosa Chacón, Gloria Patricia Marciales Vivas, and Harold Castañeda Peña supports this conclusion.

While these studies have explored how IL should be defined, far fewer articles describe how IL practices are understood within specific communities. In Spain, several studies describe surveys that are designed to test academic IL skills, but they provide little detail about student 
experiences and activities beyond noting high levels of motivation and perceived skills. ${ }^{32}$ These studies also highlight the importance of competencies, such as information management and organization or the ability to schematize and abstract information. ${ }^{33}$ Research in Latin America has been similarly limited to surveys of library usage. ${ }^{34}$ In one study, however, Nancy Gómez found that the information practices of physics doctoral candidates center on collecting, confirming, rejecting, finalizing, and communicating ideas. Gómez also determined that there are different information needs (including the ability to work with English materials) associated with each stage of research. ${ }^{35}$ César Augusto Ramírez Velázquez’s 2007 research into indigenous information practices hints at the diversity of language and cultural backgrounds that characterize incoming Spanish-speaking students. ${ }^{36}$ Overall, however, few studies have explored these practices in any detail.

The widespread usage of Spanish within the United States means that findings from a survey of U.S.-based and non-U.S.-based Latin Americanist graduate students provide a snapshot of Spanish-language information landscapes ${ }^{37}$ English is one of the primary languages in the field, but students also use materials in "French, Quechua, Mayan, German, Dutch, Italian, Mixtec, Latin, and Spanglish." ${ }^{\prime 3}$ Because of this diversity, Latin American students may already have considerable experience dealing with linguistic information issues. Few other studies of Spanish speakers in the United States address the question of language within information experiences, beyond positioning it as a barrier to engagement and inclusion. ${ }^{39}$ One exception, however, is Alison Hicks's 2014 study of bilingual workers in the United States, which found that professionals develop various strategies to engage with Spanish information in a majorityEnglish world. ${ }^{40}$ While the study did not focus on students, it provides evidence of the inherent complexity of multilingual research. 


\section{International Graduate Student IL Practices}

Within the English-speaking world, a number of studies have focused on international student IL practices over the last 10 years. Amanda Click, Claire Wiley, and Meggan Houlihan as well as Karen Bordonaro attribute interest in such students to the growing internationalization of campuses. ${ }^{41}$ However, this attention has not yet translated into corresponding methodological variation. Most studies of international student IL still focus on undergraduates and the measurement of student skills against a variety of standardized tests such as the ACRL Information Literacy Standards for Higher Education. ${ }^{42}$ Similarly, the few studies that center upon international graduate students have tended to take a behaviorist approach to IL and to focus, somewhat narrowly, on the barriers that these students face when they arrive in the United States. ${ }^{43}$ Literature from the 1990 s, for example, overwhelmingly centers on the language and cultural issues perceived to prejudice international students' adjustment to English-speaking settings. ${ }^{44}$ Linked to the apparent lack of IL training as well as to differences in libraries around the world, these studies find that "different cultural body language and gestures, social class and religious differences, traditional passive roles of learners, and shyness about approaching authority figures for assistance" could affect graduate student capacity to do research. These ideas seem based on the notion that international students must be socialized and assimilated into local practice rather than allowed to adjust. ${ }^{45}$

By the 2000s, however, these notions had largely dissipated. Research by Yao Chen and Cecelia Brown; by Yan Liao, Mary Finn, and Jun Lu; and by Guoying Liu and Danielle Winn found that intervening technological developments had given similar research opportunities to the international graduate students as to their U.S. counterparts. ${ }^{46}$ In focusing heavily on barriers, only a handful of researchers explored the IL practices of international graduate students in any 
detail, including the issues that students might run into or the tactics they might employ in the face of information disconnect in a new setting. Exceptions include Jinghe Han and Liz Cooper and Hilary Hughes, who focus on the unique strategies that multilingual students use in reconstructing their information landscapes (such as Googling an author's gender). ${ }^{47}$ Carole George, Alice Bright, Terry Hurlbert, Erika Linke, and Gloriana St. Clair as well as Rachel Fleming-May and Lisa Yuro take these ideas even further by hinting at the links between international graduate student frustration at not knowing who to ask about information problems and the challenges of fractured social capital— that is, the fractured network of social connections between people and the support it might have provided—within a new location. ${ }^{48}$ Coupled with the acknowledgment that global academic transitions may be highly emotional, ${ }^{49}$ these studies represent a welcome move away from research that has typically characterized the international student as having some sort of deficit.

\section{Methods}

\section{Focus Groups}

The overarching goal for this project was to learn from students about their research skills and experiences. Focus groups provided a dialogue-based approach, ensuring that students' voices remained central to our data collection. ${ }^{50}$ After Institutional Review Board approval, the authors recruited 21 Spanish-speaking students through e-mails, electronic invitations on Eventbrite, and a flyer posted on the University of Kansas Latin American Graduate Organization Facebook group. ${ }^{51}$ The study invitation specifically sought Spanish-speaking graduate students to participate in the focus group. Due to the complications of compensating international students with cash, the researchers instead offered pizza and beverages as an incentive for the students' participation. The librarian at the University of Kansas held focus groups in a meeting room in 
the library and audio recorded three sessions, each of which lasted approximately one hour. Students were encouraged to speak in whichever language or languages they felt most comfortable. Most of the time, Spanish was the language of choice, with some English sprinkled throughout the conversations in all three groups. Students were prompted with the following:

- Tell me about your experiences of research.

- What have been the most successful research strategies for you to date?

- What does a good researcher look like in your opinion and in your country? What advice would you give to anyone who was studying abroad and had to do research in your country?

- How do you feel at the prospect of doing research in graduate school? What are you most/least looking forward to about researching?

The focus group setting allowed for natural conversation flows as well as follow-up questions between the researcher and the students. Students at first hesitated to speak because of the broad scope of the questions, but once the conversation started, they began relating to one another's comments and managing the conversation themselves.

\section{Respondents}

The authors held three focus groups of between six and eight master's and $\mathrm{PhD}$ students, with a total sample of 21 students. Although differences exist between $\mathrm{PhD}$ and master's-level students, for this study the authors decided not to separate students based on their level of study. Students came from 10 different countries and showed a wide range of language diversity. Besides English and Spanish, they spoke Portuguese (52 percent), Italian (23 percent), French (19 percent), Galician (14 percent), German (9 percent), and Quechua (4 percent). 


\section{Coding and Analysis}

Each of the three authors participated in the data coding and analysis process. Working from the audio recordings and focus group notes, each author individually used an emergent coding process to attach keywords or descriptions to major themes that arose from participants' comments, rather than creating codes beforehand and applying them to the comments. These codes were then refined to ensure that the themes represented the opinions of the entire group rather than those of only a few members. ${ }^{52}$ The authors also listened for agreement and disagreement between students, as well as working to distinguish the intent behind comments that sometimes seemed off-topic..$^{53}$

\section{Findings}

\section{Grasping at Straws}

Responses from the focus groups overwhelmingly demonstrate that, as new researchers in the United States, students are often frustrated by their first scholarly experiences in graduate school. Uncertain about where to begin their research as well as which tools and sources are considered appropriate within their new setting, students often grasp at straws or try any strategy that they can think of to orient themselves to their information landscape. This approach leads to scattershot or haphazard initial approaches to research. Confusion and fear also mark this period as students work to align their previous research experiences with the expectations and pressures of a new academic environment.

One of the major problems that these new graduate students face centers on where to start their research, particularly for topics that are new to them or for which they have received little guidance. While they had often developed strategies to find the information they needed as undergraduates, students find that the new expectations placed upon them, such as the need to 
research unfamiliar literary terms and theories, means that these previously-used tactics do not always carry over to a new setting. Original quotations appear in the following paragraphs, with translations in parentheses when necessary:

Yo no sé cómo buscar teoría, entonces, porque todos los profesores dicen "busca teoría y después un tema o una obra" ... pero realmente no sé cómo buscar teoría. (I don’t know how to search for theory, so, because all the professors say, "Look for theory and then a topic or a work" . . but really, I don't know how to find theory.)

Uncertain about both the nature of this information as well as where it might be found, students' first instinct is to cast a wide net or to carry out broad and scattered searches in large search tools, such as Google or the library catalog. Students perceive search engines such as Google as reliably providing an answer and also as a nonjudgmental resource that will quickly and silently help them mediate their lack of knowledge in the field:

Uso Google y puedes poner las cosas más tontas y pun te sale, "cuál es la teoría," "los teóricos más importantes de la eco-crítica" y pun te salen y "cuál es la teoría, no sé, estructuralista" y pun te salen. (I use Google and you can put in the stupidest things, and boom, something comes up, "what is the theory," "who are the most important theorists of eco-criticism," and boom, something comes out, and what is, say, "structuralist theory," and something comes out.

At the same time, students recognize that Google can contribute to the sense of helplessness that they feel within their new information landscape. When students do find information that they think could be related to their topic, their lack of experience in the field means that they struggle to sort through and evaluate the results that they have pulled up:

En Google Scholar te salen un montón de búsquedas, pero [no sé] por dónde empezar. Y también tengo el problema de [no saber] hasta qué punto es una fuente fiable. (In Google Scholar you get a lot of results but [I don't know] where to begin. And I also have the problem of [not knowing] to what extent I can trust the source.) 
This strategy, or lack of strategy, poses several challenges for the students. Primarily, this approach is labor-intensive and requires large amounts of time without necessarily producing results of significant value. It also leads to students' fear that, in grasping at straws within these large search tools, they might miss or overlook a vital piece of information:

No sé exactamente utilizar bien las comillas o cuando poner el $O R$, o cuando poner toda esa nomenclatura, siempre me pierdo entonces por no saber usarla, creo que me estoy perdiendo muchas cosas. (I don't exactly know how to use the quotation marks or when to put an $O R$ or when to use all that nomenclature, I always get lost, and because I don't know how to use it, I believe that I am missing many things.)

Grasping at straws, a consequence of their transition from undergraduate- to graduatelevel work, demonstrates students' initial attempts to build an understanding of their new information landscape. As newcomers to the United States, however, grasping at straws may be complicated by the lack of emphasis on research in their home country:

En la licenciatura no hacemos investigación. Por lo menos en España y en lo que es las filologías, los idiomas no hacemos mucha investigación. Ya nos dan los artículos que consideran los profesores o si no, nos recomiendan un autor directamente ... para no hacernos "perder" el tiempo, entre comillas. (At the bachelor's level, we do not do research. At least in Spain, in literature, languages we do not do much research. The professors give us the articles [that we need] or recommend an author ... so we do not "waste" time.)

The sudden increase in the library resources available to them also magnifies the students' sense of being overwhelmed. Almost every student highlighted the disconcerting effect that this expanded suite of services (such as interlibrary loan) and abundance of materials had on their research:

La universidad no tenía el acceso como tiene $\mathrm{KU}$, por ejemplo, tantas bases de datos, tantos libros. Básicamente era búsqueda por Internet y aquí en cambio es todo diferente, libros, esos libros te llevan a otros libros en lugar de buscar todo por Internet. (The university didn't have access like 
KU has, for example, so many databases, so many books. Basically, it was research on the Internet, and here, it's all different, books, those books lead you to other books instead of searching for everything on the Internet.)

Forcing students to scale up both their expectations and their information activities adds to the uncertainty that they feel.

\section{Mastering the Canon}

As students adjust to their new academic setting, they become aware of the emphasis placed on the canon of literature that forms the heart of their discipline. Encapsulating the core scholarly ideas and frames of reference within a field of study, these works also represent the knowledge that students must master as they develop in the field. Mastering the canon serves to focus student activity upon the elicitation and discovery of key disciplinary resources as well as the authors and texts that structure a subject and constitute expert knowing. This process shapes student information activities as they look to expand their knowledge of the field.

One of the major challenges that these students encounter centers upon the need to determine what works constitute the canon. Unsure about both the shape of their new field of study and the nature of North American research traditions, students often turn to tools that they perceive as trustworthy and reliable guides to their new subject area. They see bibliographies, for example, as a useful and reliable shortcut into a topic:

Las bibliografías anotadas sí me han servido ... me ayuda como a no quedarme navegando en un mar de fuentes, sino en concreto qué voy a utilizar, por qué lo voy a utilizar. (Annotated bibliographies have been useful . . they help me avoid navigating a sea of sources, but instead, what am I going to use, why I am going to use it.)

The thoroughness of dissertations as well as their extensive review process means that students rely on published doctoral work to serve a similar purpose: 
Buscar una tesis que ya se hayan escrito sobre el tema, allí es donde está como la fuente de todo lo que se está diciendo, se ha dicho del tema que te interesa o que te puede interesar y allí es donde he encontrado joyas. (Find a thesis that have already been written on a topic, this is where there is like the source of everything that is being said, that has been said of the topic that interests you or might interest you and there is where I have found gems.)

Providing students with a comprehensive yet succinct overview of core research in the field, the bounded nature of these sources provides them with the user-friendly introduction that students need to become more confident and knowledgeable about the field.

Beyond relying on specific genres of materials, a second major challenge that students face centers upon establishing what research is valued and trusted in the field. Confronted with the need to master a new discipline as well as being highly aware of the differences between North American and Spanish or Latin American disciplinary traditions, students are often unsure about what constitutes core research in their field. They may develop a variety of idiosyncratic strategies and tactics to help them assess whether a resource would be considered appropriate. For many students, the number of citations provides a clue about the value of an item in their field:

I pay attention to how often each article or book is cited, I want everything that's written on the topic in the past 10 years and then everything before that that is still oft cited, I consider it must be canonical in some way if people are still talking about it so much.

For others, the repetition of familiar names alerts them to an author's importance:

Si ves el nombre muchas veces, si ves Mignolo, Mignolo, Mignolo, más o menos confías que Mignolo tiene que ser uno de los principales, hay que leer y ver que nombres aparecen bastante. (If you see a name several times, if you see Mignolo, Mignolo, Mignolo, you more or less trust that Mignolo has to be one of the major [scholars], you have to read and see which names appear quite frequently.) 
In using these external markers as a proxy for quality rather than drawing upon the content or the research approach of a source, students demonstrate both their inexperience and their purposeful use of the resources available to them as they develop their understanding of the field.

In the same vein, students talk to trusted contacts about what is valued in their area of study. In asking for the sources that his professor thinks are "important," for example, this student looks for direct insight into experienced or knowledgeable ways of thinking: "Iba a un profesor de medieval, y le preguntaba por autores que él creía importantes.” (I used to go to a professor of medieval [studies], and I would ask him about authors that he thought were important.)

Students with more seniority may not have the same knowledge as faculty, but their experience or success within the program means that recently arrived students rely on them in a similar way:

También pregunto a [otra estudiante]; a veces le pregunto sobre ciertos autores, o ciertos sitios donde puedo ir a buscar cierta información porque ellos tienen mucho más experiencia o a lo mejor es el tema que tratan entonces me pueden ayudar más. (I also ask [another student]; sometimes I ask her about various authors, or certain places where I can go to find information because they have much more experience, or sometimes it's the topic they are working on so they can help me more.)

Trusted because of their experience and expertise, professors and members of their cohort are seen to provide both reliable and accessible insights into the workings of the field. This is particularly the case for students who may have lost the familiar frames of reference that they previously used, for example, the professors who recommended and loaned books to them in their home country. In addition, the interdisciplinary nature of U.S. scholarship and libraries means that students who are accustomed to small, subject-based libraries where only canonical sources are provided must develop completely new ways of evaluating resources: 
En la biblioteca a la que estoy acostumbrada . . no tenía tantos recursos, entonces, todo estaba como acotado, y sólo estaba lo canónico, entonces no eran tantos problemas. (In the library to which I am accustomed . . . it didn't have as many resources, so everything was next to each other, and there was only the canonical, so there were no problems.)

Mastering the canon demonstrates the importance of core disciplinary knowledge to the development of student competence and expertise within a new academic context. It also highlights the range of textual, tool-specific, and social sources that students use to mediate uncertainty within their new information landscape.

\section{Making Their Mark}

As students master the canonical literature of the field, their growing sense of expertise and confidence means that they start to focus upon how they can make their mark or establish their own contributions to the field. Mediated through their ongoing specialization within a discipline, students desire to carve out a niche for themselves as they prepare for a future as members of the academy. Tightening job markets as well as the financial and emotional investment that students have made to study overseas add to students' uncertainty as they negotiate the complexity of a multicultural academic world.

Most importantly, students' desire to make their mark on the field starts to change the way that they look for information. Rather than relying on the online and print sources from which they could ascertain the canonical works in the field, their increasing expertise means that their professional communities become far more important for research than the library:

Las redes sociales ... se utilizan más ... han abierto otras puertas para hacer investigación ... hay un grupo en Facebook que se llama Mexicanists across Academies . . . si hay cosas que pueden entrar dentro del día a día, las noticias de nuevas publicaciones ... [si] tienes una duda. (Social media, which is used more because it opens other doors to do research . . . there is a group on Facebook which is called Mexicanists across Academies ... there are things that enter into daily life, news of new publications ... if you have a question.) 
The ability to make connections with other scholars working on related topics provides a way for students to engage, as one participant put it, "at the cutting edge" of their field. It also helps students to build the professional networks that will sustain them in their future careers.

Students' wish to contribute to the field also starts to change the sources that they use. Cognizant that sources in Spanish or from their home country may be less known and valued within the North American academy, students consciously seek out more diverse forms of information:

Tenemos que también incorporar de alguna forma lo que escriben en otras partes del mundo ... si no, estamos como "being inbred" . . siempre repitiendo las mismas palabras, las mismas formas de pensar. (We also have to incorporate somehow what people write in other parts of the world ... if not, we are "being inbred" . . always repeating the same words, the same ways of thinking.)

At the same time, students realize that their desire to be inclusive leaves them open to criticism. As the following extract from one of the focus group conversations illustrates, is ignoring an under-cited article a missed opportunity or a risk?:

Student 1: Mi adviser me dice, cuando vas a Google Books, mira cuan citados están y no me uses cosas que no están citadas por nadie (My adviser says, when you go to Google Books, look how often things are cited and don't use things which haven't been cited by anyone.)

Student 2, responding to Student 1: Es como cuando pasas por delante de un restaurante y ves que no hay nadie. Tu no vas a entrar y entonces el restaurante nunca se va a llenar y a lo mejor es bueno, pero... (It's like when you pass by a restaurant and you see nobody's there. You won't go in, so the restaurant is never going to fill up; and maybe it's good, but...)

Making their mark also demonstrates the tension between students' wish to be creative and to find an entrée into academic conversations.

Tension can also develop as students start to choose the topic for their dissertation or thesis. While their advisers encourage students to select a topic that both interests them and fills 
a hole in the literature, the ongoing scarcity of academic positions means that students also operate under the pressure to produce work that is marketable and that can help them get a job:

He escuchado a profesores que me aconsejan — porque yo quiero trabajar en los Ándes y en el cine indígena - "Sí, pero es que las universidades ahora no les interesan los Ándes, lo que está de moda es México ... Si vas a trabajar en eso, no te va a ayudar a conseguir trabajo, o te va a dificultar." Entonces, el temor mío es, lo que yo quiero versus lo que me va a ayudar a conseguir trabajo. (I have listened to professors who have advised me- because I want to work on the Andes and indigenous cinema-"Universities today aren't interested in the Andes, what is in fashion is Mexico ... If you're going to work with [the Andes], you won't get a job, or it will be really difficult"... So my fear is, what I want versus what will help me to get a job.)

The sense of responsibility that students feel toward their home country heightens these pressures. Students' desire to make a mark within the academy is further complicated by their wish to make their research useful for people back home, too:

Que tenga un impacto social, especialmente por la coyuntura en la que estamos. Es decir, que tu investigación sirva para mejorar las condiciones de la vida de las personas. Y si se puede, [a] las que más necesitan. (That it should have a social impact, especially in the situation we're in. That's to say, your research should serve to improve the condition of people's lives. And if possible, [help] those who need it the most.)

Intensified by their recognition that the language of the academy is very different from the language used by the people they research and hope to affect, these comments illustrate the pressures that students meet as they attempt to craft and hone their academic reputation. Affecting both the way they approach potential sources and how they evaluate and make use of the information they find, the desire to make a mark also demonstrates the complexity of Spanish-speaking students' transition into academia.

\section{Discussion}


Centered upon students' graduate school experiences, our findings demonstrate that Spanishspeaking students develop a wide range of information activities and strategies to help them navigate important academic transitions.

\section{From Student to Academic: Reorientation}

The transition from undergraduate to academic forms the major focus of students' information activities during their time in the United States. While students have often engaged with a series of nuanced information practices to meet the challenges of their undergraduate studies in their home country, the different emphases and pressures of graduate school mean that their strategies do not transfer neatly to their new setting. Affecting both the shape of the information with which students engage and the purpose to which they put it, these changes highlight how, although students arrive with a sophisticated understanding of their home information landscape, they need to develop new situated ways of knowing within their new setting. Grasping at straws and mastering the canon help students to decipher and align themselves with both the explicit and the tacit or rarely talked about rules and values that regulate their new scholarly context. By doing so, they can affiliate with their new discipline and build up the comprehensive understanding needed to be taken seriously as scholars. ${ }^{54}$ In further enabling students to engage with the esoteric sources and different perspectives that they want to bring to their research, information activities directed at making their mark also help students to contribute to their field.

Many studies of international students imply that they arrive on campus with low levels of IL skills. ${ }^{55}$ This research, on the contrary, illustrates that students take part in a sophisticated process of reorienting and engaging with the information activities that will help them to build understanding within a new setting, even though these activities may not be recognized as standard librarian practice. Highlighting how students scale up and adjust their information 
activities to cope with the wider range of resources available to them as well as to reorient themselves to different academic expectations, this study further illustrates how students use any resources at their disposal, including people, print bibliographies, and Google, to develop an understanding of their new setting. Underscoring the complex multimodality of IL practice, this study also demonstrates the high-stakes pressures and emotions that structure student transitions as they adjust to a new information environment. ${ }^{56}$ These tensions are not unique to Spanishspeaking graduate students, as Barbara Blummer, Sara Lohnes Watulak, and Jeffrey Kenton point out in their study of education graduate students. ${ }^{57}$ However, students' newcomer and international status may intensify their emotional challenges, as Hilary Hughes found in her study of undergraduate international students. ${ }^{58}$

\section{From Spanish to English Academic: Fitting in and Standing Out}

The transition to a North American academic forms the other major focus of student information activities. Due to the important role that English plays in academia as well as in publishing, these students already have considerable experience doing research in English. Although some authors characterize language as a barrier to undergraduate information use,$^{59}$ this study demonstrates that working in a second or third language barely seems to affect these graduate students' information skills, such as searching in a database. Students often encounter challenges, however, from the different expectations of the North American academy. Accordingly, IL practices can facilitate the transition to North American academic traditions by helping students to reframe and construct their engagement within their new information landscape. Enabling students to recognize U.S. values about what constitutes a good source, for example, can help students become oriented to the North American models of academia against which their research will be judged. 
At the same time, this transition can also create considerable tension as students grapple with, and attempt to reconcile, complicated questions about the nature and purpose of their multilingual and multicultural academic identities. Among students studying overseas, many of their research interests emerged from their engagement with, and recognition of, issues in their home communities. These students remain deeply committed to the social usefulness of their graduate studies. Accordingly, making their mark also enables students to bridge and integrate their Spanish-speaking and English-speaking worlds by facilitating their engagement with the Spanish-language sources and perspectives that they perceive are missing from North American academic practices. These pressures can also cause tension, particularly when student goals of fitting into and standing out from North American academia conflict, as illustrated through recommendations to avoid uncited works or to choose a marketable topic. Affecting both the emphasis and the shape of their information activities, these tensions further highlight the complexity and emotional intensity of these students' graduate school experiences. ${ }^{60}$

\section{Recommendations}

Helping the authors to understand how Spanish-speaking graduate students approach research, the findings from this study sparked an array of ideas for future studies as well as for the design of more appropriate research support structures. Firstly, the librarian at the University of Kansas modified the orientation session for international students in the Department of Spanish and Portuguese. One author tried to make it more of a dialogue geared toward exploring, understanding, and validating students' previous experiences with research and libraries as well as the librarian's role as a partner in their studies. In place of the traditional fast-paced workshop on how to navigate the library web page and its databases, the librarian focused on a tour of the library and the location of key offices, which students identified as overwhelming in this study. 
In addition, the librarian decided to spread out in-depth information about research practices over a year in a series of workshops. In the fall, the workshops focus on researching in international archives as well as decolonizing academia (discussing tools and resources focused on open access journals and scholars from outside the United States). In the spring, the focus turns to scholarly communication, data management, and citation management. Working with stakeholders will ensure that all needs are considered instead of librarians imposing their preconceived notions of what students require. The goal is twofold. On the one hand, we aim for a participatory process. On the other, we also strive to meet the students when they need the information and provide it in small doses rather than all at once during their marathon orientation before the semester begins.

Another author has reorganized an orientation session for graduate students in the Department of Spanish and Portuguese to include information about the themes identified through this study. Instead of a classic overview of the library website, tools, and services, the librarian centers discussion around what to do when grasping at straws, including ideas or tools, how to use library resources to master the canon, and using scholarly communication services to make one's mark. This author hopes to use student feedback to expand the orientation session into a series of workshops that address these major themes of a graduate student's transition at strategic times during their studies rather than in a one-shot orientation. Workshops could include focus on mastering the canon, which teaches students how to map key authors and works in the field, as well as making one's mark, which would center upon information sharing and scholarly communication as students look to mediate their identity as a scholar and as a multilingual researcher. 
The authors have also begun to experiment with some additional ideas. One author has started to create Web tutorials in the form of narrated slide presentations designed around the findings of the study for asynchronous instruction, which could be deployed when librarians cannot participate in student orientations for lack of time or lack of stakeholder buy-in. Another colleague facilitates optional monthly or twice-monthly meetings in the library that explore emerging issues related to graduate student experiences with research, presentation skills, and scholarly communication. Because the sessions are led by graduate students, the librarian learns from the students about their needs while working with them to address questions and issues as they emerge. The librarian sustains a conversation with the graduate students over time, which allows him to ask for clarification, avoid making assumptions, and meet their needs in a timely manner.

In future, the authors also recommend continuing this research to explore whether the findings of this study are applicable to other cohorts of international students beyond Spanish speakers. Similarly, future research could explore whether there are differences and implications for IL teaching between heritage-speaker and international students, including those who have previously studied in the United States. Future studies could also broaden the scope of this research by exploring IL practices beyond an academic setting. Recognizing that international graduate students engage in several transitions when they relocate overseas, future research could explore how everyday changes, including differences in leisure, travel, and recreation, are facilitated through the enactment of IL practices.

\section{Conclusion}

Spanish-speaking students are uniquely poised to bridge culture gaps and to promote cultural understanding through their work. As students work toward these ideals, librarians can look for 
opportunities to intervene at moments of need in these students' transition from undergraduate to graduate student, and from Latin American or Spanish scholar to academic in an Englishdominated information landscape. If the students' own experiences and knowledge inform the librarians' practice, the librarians will have more success in improving students' experience than if they were to judge the students against a rigid set of standards. Building upon students' knowledge, their attempts to grasp at straws, and their desires to master the canon and make their mark, the librarian can work to co-create and co-facilitate instruction, services, and resources that meet the complex and emerging nature of students' information-related goals.

Betsaida M. Reyes is the librarian for Spanish, Portuguese, Latin American, and Caribbean studies at Watson Library of the University of Kansas in Lawrence; she may be reached by emailat:breyes@ku.edu.

Alison Hicks is a lecturer in the Department of Information Studies, University College London; shemay be reached bye-mail at: a.hicks@ucl.ac.uk.

Bronwen K. Maxson is the librarian for Romance Languages at Norlin Library of the University of Colorado Boulder; she may be reached by e-mail at: bronwen.maxson@colorado.edu.

\section{Notes}

1. University of Kansas, "KU Part of New National Study Highlighting the Best in Research and Graduate Education," news release, September 28, 2010, http://archive.news.ku.edu/2010/september/28/nrcreport.shtml. 
2. American Council on Education (ACE), "Internationalizing U.S. Higher Education: Current Policies, Future Directions,” 2017, http://www.acenet.edu/newsroom/Pages/Internationalizing-U-S-Higher-Education-Current-Policies-FutureDirections.aspx.

3. Institute of International Education (IIE), "Research and Insights—-Open Doors—DataInternational Students: All Places of Origin,”2015, https://www.iie.org/Research-andInsights/Open-Doors/Data/International-Students/All-Places-of-Origin.

4. Ibid.

5. Pamela A. Jackson and Patrick Sullivan, eds., International Students and Academic Libraries: Initiatives for Success (Chicago: Association of College and Research Libraries [ACRL], 2011); Karen Bordonaro, Internationalization and the North American University Library (Lanham, MD: Scarecrow Press, 2013); Steven W. Witt, Laurie Kutner, and Liz Cooper, "Mapping Academic Library Contributions to Campus Internationalization," College \& Research Libraries 76, 5 (2015): 587-608.

6. Alison Hicks and Annemaree Lloyd, "It Takes a Community to Build a Framework: Information Literacy within Intercultural Settings," Journal of Information Science 42, 3 (2016): 334-43, doi:10.1177/0165551516630219.

7. Miriam Conteh-Morgan, “Journey with New Maps : Adjusting Mental Models and Rethinking Instruction to Language Minority Students," in Hugh Thompson, ed., ACRL Eleventh National Conference Proceedings, April 10-13, 2003, Charlotte, North Carolina (Chicago: ACRL, 2003).

8. Joanne Larson and Jackie Marsh, Making Literacy Real: Theories and Practices for Learning and Teaching (London: Sage, 2014), 101. 
9. Sanna Talja and Annemaree Lloyd, "Integrating Theories of Learning, Literacies and Information Practices," in Sanna Talja and Annemaree Lloyd, ed., Practising Information Literacy: Bringing Theories of Learning, Practice and Information Literacy Together (Wagga Wagga, Australia: Centre for Information Studies, 2010), xii.

10. Hicks and Lloyd, "It Takes a Community to Build a Framework."

11. Annemaree Lloyd, Information Literacy Landscapes: Information Literacy in Education, Workplace and Everyday Contexts (Oxford: Chandos, 2010).

12. Ibid.

13. Kris D. Gutiérrez and Barbara Rogoff, "Cultural Ways of Learning: Individual Traits or Repertoires of Practice," Educational Researcher 32, 5 (2003): 19.

14. Dennis Saleebey, The Strengths Perspective in Social Work Practice (Boston: Pearson Education, 2009).

15. Rosemary Green, "Information Illiteracy: Examining Our Assumptions," Journal of Academic Librarianship 36, 4 (2010): 314, doi:10.1016/j.acalib.2010.05.005.

16. Lloyd, Information Literacy Landscapes.

17. ACRL, Framework for Information Literacy for Higher Education, 2015, http://www.classes.ala.org/mod/resource/view.php?id=33804.

18. Félix Benito Morales, “Del Dominio de La Información a la Mejora de la Inteligencia. Diseño, Aplicación y Evaluación del Programa HEBORI [Habilidades y estrategias para buscar, organizar y razonar la información—Skills and strategies for finding, organizing, and reasoning information] [From mastering information to the improvement of intelligence: design, application, and evaluation of the HEBORI program]," PhD diss., University of Murcia, Spain, 1996). 
19. Tony Hernández-Pérez, Ana Reyes Pacios, Marina Vianelllo, Raul Aguilera Ortega, and Mayte Ramos Gorospe, “La formación en alfabetización en información en las aulas universitarias: el caso de la UC3M [Universidad Carlos III de Madrid] [Training in information literacy in university classrooms: The case of UC3M]," Scire: Representación y Organización del Conocimiento [Scire: Representation and organization of knowledge] 17, 2 (2011): 27-37, http://ibersid.eu/ojs/index.php/scire/article/viewArticle/3927.

20. International Federation of Library Institutions and Associations (IFLA), Committee on Free Access to Information and Freedom of Expression, "Directrices del Manifiesto IFLA/UNESCO Sobre Internet [Guidelines of the IFLA/UNESCO manifesto on the Internet]," 2006, 27, http://archive.ifla.org/faife/policy/iflastat/Internet-ManifestoGuidelineses.pdf.

21. Alejandro Uribe-Tirado and Astrid Girlesa Uribe, "La alfabetización informacional en las universidades españolas [Information literacy in Spanish universities]," Revista Española de Documentación Cientifica [Spanish journal of scientific documentation] 35, 2 (2012): 32545, doi:10.3989/redc.2012.2.873.

22. Alejandro Uribe Tirado, "Niveles de desarrollo de los programas de formación en habilidades informativas-alfabetización informacional en universidades mexicanas según la información de sus sitios Web [Levels of development of training programs in informational skills-information literacy in Mexican universities according to the information on their websites]," Investigación Bibliotecológica : Archivonomía, Bibliotecología e Información [Library science research: Archivonomics, library science, and information] 26, 58 (2012): 121-51, http://www.scielo.org.mx/scielo.php?pid=S0187358X2012000300006\&script=sci_arttext. 
23. María Pinto, M. Isabel Escalona, Antonio Pulgarín, and Alejandro Uribe-Tirado, "The Scientific Production of Ibero-American Authors on Information Literacy (1985-2013)," Scientometrics 102, 2 (2015): 1571.

24. Edilma Naranjo-Vélez and Nora Elena Rendón-Giraldo, "Explorando el panorama de la formación de usuarios de la información [Exploring the landscape of information user training]," Revista Interamericana de Bibliotecología [Inter-American journal of library science] 26, 2 (2003): 13-37, http://www.redalyc.org/html/1790/179018081002/.

25. Elisabeth Adriana Dudziak, "Information Literacy and Lifelong Learning in Latin America: The Challenge to Build Social Sustainability," Information Development 23, 1 (2007): 4347.

26. Pinto, Escalona, Pulgarín, and Uribe-Tirado, "The Scientific Production of Ibero-American Authors on Information Literacy."

27. Dudziak, "Information Literacy and Lifelong Learning in Latin America," 45.

28. IFLA, "Havana Declaration,” trans. Jesus Lau, Mari Carmen Torrás, and Sean Cordes, 2012, https://www.ifla.org/node/6964.

29. Alejandro Uribe Tirado, “Alfabetización Informacional [Information literacy]—ALFIN (Alfabetización Informacional)/ Colombia,” blog, 2017, http://alfincolombia.blogspot.com/.

30. Gloria Ponjuán, María Pinto, and Alejandro Uribe Tirado, “Conceptualización y perspectivas de la alfabetización informacional en Iberoamérica: Un estudio Delphi [Conceptualization and perspectives of information literacy in Latin America: A Delphi study]," Information Research 20, 3 (2015), http://www.informationr.net/ir/20-3/paper680.html\#.Vli179Ivfcs.

31. María Pinto, Gloria Ponjuán, Mercedes Fernández, and Dora Sales Salvador, “Information Literacy Life Cycle and Its Standards and Models: A View from Ibero-America,” Journal of 
Librarianship and Information Science (2016), doi:10.1177/0961000616654750; Maria

Lourdes Tiscareño Arroyo and José de Jesús Cortés-Vera, "Competencias informacionales de estudiantes universitarios: una responsabilidad compartida. una revisión de la literatura en países latinoamericanos de habla hispana [Information competencies of university students as a shared responsibility: A review of literature in Latin American Spanish-speaking countries]," Revista Interamericana de Bibliotecología 37, 2 (2014): 117-26, http://eprints.rclis.org/23259/1/v37n2a1.pdf; Jorge Winston Barbosa Chacón, Gloria Patricia Marciales Vivas, and Harold Castañeda Peña, "Caracterización de la competencia informacional y su aporte al aprendizaje de usuarios de información: una experiencia en la formación profesional en psicología [Characterization of information competence and its contribution to the learning of information users: An experience in professional training in psychology]," Investigación Bibliotecológica: Archivonomía, Bibliotecología e Información 29, 67 (2015): 47-76, doi:10.1016/j.ibbai.2016.02.036.

32. María Pinto and Dora Sales, "Insights into Translation Students' Information Literacy Using the IL-HUMASS [Information Literacy Humanities and Social Sciences] Survey," Journal of Information Science 36, 5 (2010): 618-30; and María Pinto, Andrés Fernández-Ramos, Gerardo Sánchez, and Grizly Meneses, "Information Competence of Doctoral Students in Information Science in Spain and Latin America: A Self-Assessment," Journal of Academic Librarianship 39, 2 (2012): 144-54, doi:10.1016/j.acalib.2012.08.006.

33. María Pinto and Dora Sales, "A Research Case Study for User-Centred Information Literacy Instruction: Information Behaviour of Translation Trainees," Journal of Information Science 33, 5 (2007): 531-50, doi:10.1177/0165551506076404; María Pinto, “An Approach to the 
Internal Facet of Information Literacy Using the IL-HUMASS Survey," Journal of Academic Librarianship 37, 2 (2011): 145-54.

34. José de Jesús Cortés-Vera, "Semejanzas y diferencias entre estudiantes norteamericanos y mexicanos como usuarios de la información: una aproximación a su estudio [Similarities and differences between North American and Mexican students as users of information: An approach to their study]," in Información sin fronteras: Compartición de experiencias sobre bibliotecas y centros de información [Information without borders: Sharing experiences of libraries and information centers], comp. Javier Tarango, Patricia Murguía, María Valverde Armendáriz, and Angélica Sandoval Pineda (Chihuahua, Mexico: Universidad Autónoma de Chihuahua, Facultad de Filosofía y Letras, 2006), 9-25; Alexa Milley Gómez Restrepo, “Comportamiento en la búsqueda de información: El caso de los estudiantes de postgrado [Behavior in information searching: The case of graduate students]," Revista Interamericana de Bibliotecologia 35, 2 (2012): 133-48.

35. Nancy Diana Gómez, "La conducta informativa de los físicos: Un estudio cualitativo de usuarios [The information behavior of physicists: A qualitative study of users]," Información, Cultura y Sociedad [Information, Culture, and Society] 4 (2001): 23-36.

36. César Augusto Ramírez Velázquez, "Las comunidades indígenas como usuarios de la información [Indigenous communities as users of information]," Investigación Bibliotecológica: Archivonomía, Bibliotecología e Información 21, 43 (2007): 209-30.

37. Orchid Mazurkiewicz and Claude Potts, "Researching Latin America: A Survey of How the New Generation Is Doing Its Research," Latin American Research Review 42, 3 (2007): 16182; Orchid Mazurkiewicz and Tim Sturm, "Researching Latin America, Part Two: A Survey 
of How the New Generation Is Doing Its Research," Investigación Bibliotecológica:

Archivonomía, Bibliotecología e Información 28, 63 (2014): 163-92.

40. Mazurkiewicz and Potts, "Researching Latin America," 168.

39. Alison Hicks, "Reframing Librarian Approaches to International Student Information Literacy through the Lens of New Literacy Studies," in Critical Literacy for Information Professionals, ed. Sarah McNicol (London: Facet, 2016), 43-56.

40. Alison Hicks, "Bilingual Workplaces: Integrating Cultural Approaches to Information Literacy into Foreign Language Educational Practices," Journal of Information Literacy 8, 1 (2014): 21-41.

41. Amanda B. Click, Claire Walker Wiley, and Meggan Houlihan, "The Internationalization of the Academic Library: A Systematic Review of 25 Years of Literature on International Students," College \& Research Libraries 78, 3 (2017): 328-58; Bordonaro, Internationalization and the North American University Library.

42. Hicks and Lloyd, "It Takes a Community to Build a Framework."

43. Ibid.

44. Yan Liao, Mary Finn, and Jun Lu, "Information-Seeking Behavior of International Graduate Students vs. American Graduate Students: A User Study at Virginia Tech 2005," College \& Research Libraries 68, 1 (2007): 5-25, doi:10.5860/crl.68.1.5.

45. Svetlana Korolev, "Chemical Information Literacy: Integration of International Graduate Students in the Research,” Science \& Technology Libraries 19, 2 (2000): 35-42, doi:10.1300/J122v19n02; Liao, Finn, and Lu, "Information-Seeking Behavior of International Graduate Students vs. American Graduate Students"; Mary R. Lea and Brian V. 
Street, "The 'Academic Literacies' Model: Theory and Applications," Theory into Practice 45, 4 (2006): 368-77.

46. Yao Chen and Cecelia Brown, "Ensuring Chinese Engineering Graduate Students' Academic Success: A Study at the University of Oklahoma," Science \& Technology Libraries 31, 3 (2012): 320-41; Liao, Finn, and Lu, "Information-Seeking Behavior of International Graduate Students vs. American Graduate Students"; Guoying Liu and Danielle Winn, "Chinese Graduate Students and the Canadian Academic Library: A User Study at the University of Windsor," Journal of Academic Librarianship 35, 6 (2009): 565-73, doi:10.1016/j.acalib.2009.08.001.

47. Jinghe Han, "Information Literacy Challenges for Chinese PhD Students in Australia : A Biographical Study," Journal of Information Literacy 6, 1 (2012): 3-17; Liz Cooper and Hilary Hughes, “First-Year International Graduate Students' Transition to Using a United States University Library," IFLA Journal 41, 4 (2017): 326-35, doi: $10.1177 / 0340035217723355$.

48. Carole George, Alice Bright, Terry Hurlbert, Erika C. Linke, Gloriana St. Clair, and Joan Stein, "Scholarly Use of Information: Graduate Students' Information Seeking Behaviour," Information Research 11, 4 (2006): 27, http://www.informationr.net/ir/11-4/paper272.html; Rachel Fleming-May and Lisa Yuro, "From Student to Scholar: The Academic Library and Social Sciences PhD Students' Transformation," portal: Libraries and the Academy 9, 2 (2009): 212, doi:10.1353/pla.0.0040.

49. Bharat Mehra, "Affective Factors in Information Seeking during the Cross-Cultural Learning Process of International Doctoral Students in Library and Information Science Education," in Information and Emotion: The Emergent Affective Paradigm in Information Behavior 
Research and Theory, ed. Diane Nahl and Dania Bilal (Medford, NJ: Information Today, 2007), 279-301.

50. Barbara M. Wildemuth and Mary Wilkins Jordan, "Focus Groups," in Applications of Social Research Methods to Questions in Information and Library Science, ed. Barbara M.

Wildemuth (Westport, CT: Libraries Unlimited, 2009), 248; Fleming-May and Yuro, "From Student to Scholar."

51. University of Kansas. Latin American Graduate Organization, Facebook 2018, https://www.facebook.com/groups/246941718844920/.

52. Wildemuth and Jordan, "Focus Groups."

53. Ibid.

54. Fleming-May and Yuro, "From Student to Scholar," 201.

55. See, for example, Korolev, "Chemical Information Literacy”; Liao, Finn, and Lu, "Information-Seeking Behavior of International Graduate Students vs. American Graduate Students.”

56. Mehra, "Affective Factors in Information Seeking during the Cross-Cultural Learning Process of International Doctoral Students in Library and Information Science Education."

57. Barbara Blummer, Sara Lohnes Watulak, and Jeffrey Kenton, "The Research Experience for Education Graduate Students: A Phenomenographic Study," Internet Reference Services Quarterly 17, 3-4 (2012): 117-46.

58. Conteh-Morgan, "Journey with New Maps"; Hilary Hughes, "International Students Using Online Information Resources to Learn," PhD diss., Queensland University of Technology, Brisbane, Australia, 2009. 
59. See, for example, Sara Baron and Alexia Strout-Dapaz, "Communicating with and Empowering International Students with a Library Skills Set," Reference Services Review 29, 4 (2001): 314-26, doi:10.1108/00907320110408447.

60. Mehra, "Affective Factors in Information Seeking during the Cross-Cultural Learning Process of International Doctoral Students in Library and Information Science Education.” 